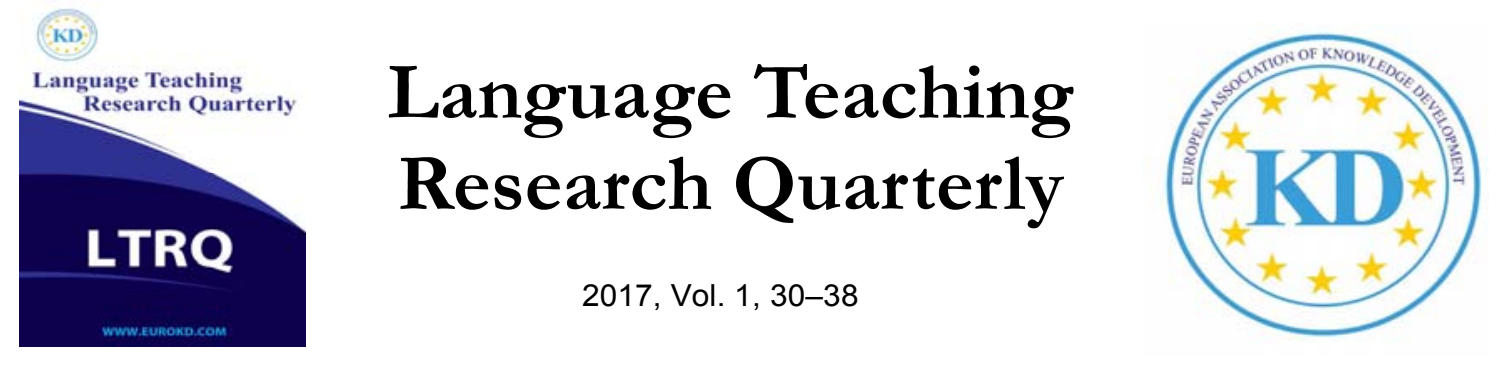

\title{
Effects of PowerPoint Presentation on Vocabulary Learning among Iranian senior high school EFL learners
}

\author{
Abolhassan Nazari ${ }^{1}$, Saeed Taki², Omid Tabatabaei ${ }^{3,}$ \\ 1,2 Department of English, Shahreza Branch, Islamic Azad University, Shahreza, Iran \\ ${ }^{3}$ Department of English, Najafabad Branch, Islamic Azad University, Najafabad, Iran
}

\begin{abstract}
Received 11 February 2017 Accepted 28 April 2017

This paper investigated the effect of PowerPoint Presentation on Iranian EFL learners Vocabulary in Chaharmahal Va Bakhtiari province. To this end, 100 Iranian high school EFL learners were selected based on their performance on PET. Then, the participants were randomly assigned into two groups (experimental and control).A pretest of vocabulary consisting words extracted from their text book was administered to determine their vocabulary knowledge prior to the treatment. Ten categories of word families were selected out of the students' text book. Afterwards, some PowerPoint presentation slides including synonyms, antonyms, parts of speech, collocations, idioms, inflections, and relevant images were designed. The word categories were taught to the experimental group using PowerPoint slides while the same words were instructed to the control group without using PowerPoint slides. To uncover the effect of treatment, a posttest similar to pretest but in reshuffled order in options and items was administered. An independent- samples $t$ test was employed for the analysis of the data. The results showed that there was a significant difference between experimental and that of control groups' performance in that experimental group's participants outperformed those of the control group. The study provides implications for language teaching pedagogy, curriculum developers, English language teachers and tutors.
\end{abstract}

Keywords: power point presentation, vocabulary, materials 


\section{Introduction}

\section{Role of Vocabulary in Language Learning}

English, as an international language, plays very important role all around the world. With the increase of communication among countries in terms of economical and cultural relations, the importance of English has been respected by Iranian people. English is one of the obligatory courses in Iranian universities for a long period. Not only those who want to be a potential teacher in the future, but also a lot of other students at colleges in Iran are interested to learn English as a essential course. We cannot deny the role of vocabulary in the process of language learning and acquisition. English courses have recently gained much attention at Iranian high schools. In the process of vocabulary learning, we should consider all different parts and aspects of the new encountered words.

If you are interested to know the meanings of new words you are referred to Taylor's seven degrees of knowing a word. He believed that we should have a good knowledge of the frequency, knowledge of the register (a speech variety used by a group of people), knowledge of collocation, knowledge of morphology, knowledge of semantics knowledge of polysemy (different meanings of a word), and knowledge of the corresponding word in the mother tongue" (Taylor, 1990, pp. 13).Some students have difficulties in retrieving and choosing appropriate words for special situations. Aitchison states that words are not just categorized haphazardly in our minds. Instead, they are classified in a ruled and complicated way which we can identify the underpinned principles (Aitchison, 2003).In Iranian high school EFL classes, teachers usually follow similar methodologies. Nevertheless, some students are able to learn and acquire a foreign language whereas the others fail. The reason might have relations to the learning facilities and equipment. A lot of learning facilities may be practical and useful for some students while ineffective for others. Many researches state that learners come with a different language learning kills and styles. It shows that the language learners should subjugate some learning styles to make their L2 learning more reasonable. Many findings also demonstrated that in addition to teaching methodologies, learners' learning styles and facilities are other decisive factors that can influence foreign language acquisition and learning. Individual learning styles can help the learners to be independent enough in language learning, and it makes learning more meaningful. That's why we say different learners have miscellaneous way of learning, and we should respect different tastes of learning including learning by current technologies.

\section{Importance of Technology}

Nowadays, access to the information is as easy as A, B, C. it has been possible for the sake of internet and the other modern technologies. You can have a good access to the published data today. If you equip yourself with information, you will be more powerful, and those who find and use information through technology are always successful. Learners can have an easy access to the information with smart phones like phablets and tablets. These kinds of smart tools help the students to enjoy the new information as well as to get information as easy as possible. 
Since technology needs great effort, it challenges the brain to work to its full capability. Technology encourages creative people to show their creativities. A lot of creative works have been done by modern technology.

A good communication is prerequisite for better learning and teaching. We cannot progress without mutual communication in any fields of study. With the development of technologies and communication tools as well as marriage of these two important domains, a lot of application appeared and simplified human communications. We can employ social networking, e-mails, smart phones, and so on.

Learning is a process and it is part of our daily lives. Modern technology provides opportunities for students to learn without boundary through distant learning, mobile learning, as well as power point presentation. All in all, students nowadays bring new technologies at the service of their learning. For example, students use Power Point presentation slides to share lessons with their classmates in the classroom. These activities made learning more comfortable and fantastic. Ultimately, new modern pedagogic technologies such as Power Point presentation slides simplify and respect individual learning which gives a possibility to students to learn on their own pace of learning with concealing contribution from teachers.

\section{Review of the Current Research on Vocabulary Instruction}

Some studies recognized and identified vocabulary as one of main constituents of reading. A lot of researchers mentioned the vocabulary is important in reading comprehension (Baker, Simmons, \& Kame'enui, 1998; Anderson \& Nagy, 1991). The National Reading Panel (NRP) stated that vocabulary is a building block in reading comprehension and learning to read, and it says we cannot get the gist of meaning without knowing the new words. "Teaching vocabulary will not guarantee success in reading, just as learning to read words will not guarantee success in reading. However, lacking either adequate word identification skills or adequate vocabulary will ensure failure" (Biemiller, 2005, pp. 24-28). We can generally define vocabulary as knowledge of word and meaning. More exactly, we call vocabulary to say the words that students are required to know and understand in order to read the text with comprehension (Kamil \& Hiebert, 2005). We cannot learn new vocabularies fly by night, it requires energy and time. A lot of studies are focusing on direct teaching of new vocabularies regarding to special text. Anderson and Nagy (1991) pointed out "there are precise words children may need to know in order to comprehend particular lessons or subject matter."(pp. 690-724) Including nativist and behaviorist view of learning exposure to language and repetition are useful in learning new vocabularies respectively. Some researchers mentioned that a mere repetition is not satisfactory. Stahl (2005) objected to "mere repetition or drill of the word," and strongly emphasized using of new words in related and repeated context. Learners should learn the vocabularies that are useful in special context. Some of the researchers stated that we should bring those high frequency vocabularies in the process of instruction that a fully grown language learner use (Beck, McKeown, \& Kucan, 2002). Some studies recommend that vocabulary learning occur step by step (Biemiller, 2001). Some studies mentioned we should introduce vocabularies in some coherent task. Kamil says we can have a vocabulary task to make 
vocabulary learning as easy as possible, and he says eve they can lean rapidly (Kamil, 2004). Vocabulary learning is more successful when it embrace active involvement rather than a mere definition. Stahl and Kapinus (2001) stated, when the learners know some vocabularies, they also know how to use different words in different contexts.

The advancement of telecommunication and computer technologies help learners to acquire new vocabularies and word families more efficiently. Motivation to use those applications in the process of vocabulary learning is growing increasingly. Some studies suggested incidental learning. Extensive reading is very important in retaining of new learned vocabularies (Cunningham \& Stanovich, 1998). In later work, Cunningham (2005) suggested discussion, read aloud whether at school or at home to extend the boundaries of vocabularies based on their interests. We should not be the slave of just one method in vocabulary learning (NICHD, 2000). Stahl (2005) stated, "Vocabulary knowledge is : the knowledge of a word not only implies a definition, but also implies how that word fits into the world."(pp. 95-114) Therefore researchers want to scrutinize, illuminate, and understand what does word family mean to students.

\section{Statement of problem}

In the last few years, the emergence of interest in Vocabulary learning, and the appearance of a newly recognized aspect-Modern technology, encourage language learners and teachers to make use of current technologies skilfully. In the field of English as a foreign language (EFL) like Iran, it is even more faithful. Because of the importance of vocabulary and technology, there are abundant research in each, yet the place where they overlap has gained a distinct lack of attention.

Language teaching and learning are clearly entering a new and largely less known phase. Students share knowledge with each other, with teachers, and the world via the technologies. In this study the researcher focused on the value of current technologies in learning some categories of word families. The study discusses Effects of PowerPoint Presentation on Vocabulary Learning among Iranian Senior High School EFL Learners.

Research questions:

1. Does power point presentation slides have any effects on Iranian EFL learners Vocabulary learning?

2. Does Iranian EFL learners learn word families much better with power Point presentation slides?

\section{Methodology}

Participants

A total of 100 male high school students were participated in this study. All the students were learning English as a compulsory course in Chaharmahal Va Bakhtiari province. They were taking vocabulary building courses in English as a Foreign Language. The participants were Iranian and native speakers of Persian. Their average age was 17 years, and all had 6 years of EFL instruction in grades 7 to 12. They were all studying English in a heterogeneous environment in which all of the students and teachers were males, and they were studying the same textbook. 


\section{Procedures}

The participants were selected based on their performance on PET. Then, the participants were randomly assigned into two groups (experimental and control). A pretest of vocabulary consisting words extracted from their text book was administered to determine their vocabulary knowledge prior to the treatment. Ten categories of word families were selected out of the students' text book. Both groups were exposed to the same categories of words families. Afterwards, some PowerPoint presentation slides including synonyms, antonyms, parts of speech, collocations, idioms, inflections, and relevant images were designed. The word categories were taught to the experimental group using PowerPoint slides while the same words were instructed to the control group without using PowerPoint slides. Training took place in eight 90-minute sessions over a four-week period. To uncover the effect of treatment, a posttest similar to pretest but in reshuffled order in options and items was administered. An independent- samples $t$-test was employed for the analysis of the data.

\section{Results}

The results showed that there was a meaningful difference between experimental and that of control groups' performance, in that experimental group`s participants outperformed those of the control group.

Table 1.the Result of the Mean of Pretest between Control and Experimental Group.

\begin{tabular}{llllll}
\hline & group & $\mathrm{N}$ & Mean & Std. Deviation & Std. Error Mean \\
\hline Pre & experimental & 50 & 11.0200 & 1.30133 & .18404 \\
& control & 50 & 11.0400 & 1.35466 & .19158 \\
\hline
\end{tabular}

As it is shown in Table 1, there is no statistically significant difference between the mean scores of these groups, (the mean score for control group is 11.040 and that for experimental group is 11.0200) therefore it was concluded that the two groups were homogeneous.

Table 2. The Results of the Independent Samples t-test of the pretest between Control and Experimental group

\begin{tabular}{|c|c|c|c|c|}
\hline \multicolumn{3}{|c|}{ Independent Samples t-Test } & $\frac{\text { Equal variances assumed }}{\text { pre }}$ & $\begin{array}{c}\text { Equal variances not assumed } \\
\text { pre }\end{array}$ \\
\hline \multirow{3}{*}{$\begin{array}{l}\text { Levene's Test for } \\
\text { Equality of Variances }\end{array}$} & & & & \\
\hline & $\mathrm{F}$ & & .026 & \\
\hline & Sig. & & .872 & \\
\hline \multirow{7}{*}{$\begin{array}{l}\text { t-test for Equality of } \\
\text { Means }\end{array}$} & $\mathrm{T}$ & & -.075 & -.075 \\
\hline & df & & 98 & 97.842 \\
\hline & Sig. (2-tailed) & & .940 & .940 \\
\hline & Mean Difference & & -.02000 & -.02000 \\
\hline & Std. Error Difference & & .26565 & .26565 \\
\hline & \multirow{2}{*}{$\begin{array}{l}95 \% \text { Confidence Interval of the } \\
\text { Difference }\end{array}$} & Lower & -.54718 & -.54719 \\
\hline & & Upper & .50718 & .50719 \\
\hline
\end{tabular}


As it is shown in this Table the t-observed is -.075 which is lower than the t-critical from the table of t-scores, so it can safely be claimed that the two groups are homogeneous in terms of their proficiency level.

Table 3. The Result of the Mean of Posttest between Control and Experimental Groups.

\begin{tabular}{llllll}
\hline \multirow{2}{*}{ post } & Group & $\mathrm{N}$ & Mean & Std. Deviation & Std. Error Mean \\
& Control & 50 & 11.8200 & 1.18992 & .16828 \\
& Experimental & 50 & 15.8600 & 1.48475 & .20998 \\
\hline
\end{tabular}

Based on the descriptive statistics presented in Table 3, in the post- test the mean score for difference for experimental group is 15.86 and that of control group is 11.82 . To show it more clear we use an independent sample $t$ test in Table 3.

Table 4. The Results of the Independent Samples t-test of the Posttest between Control and Experimental group.

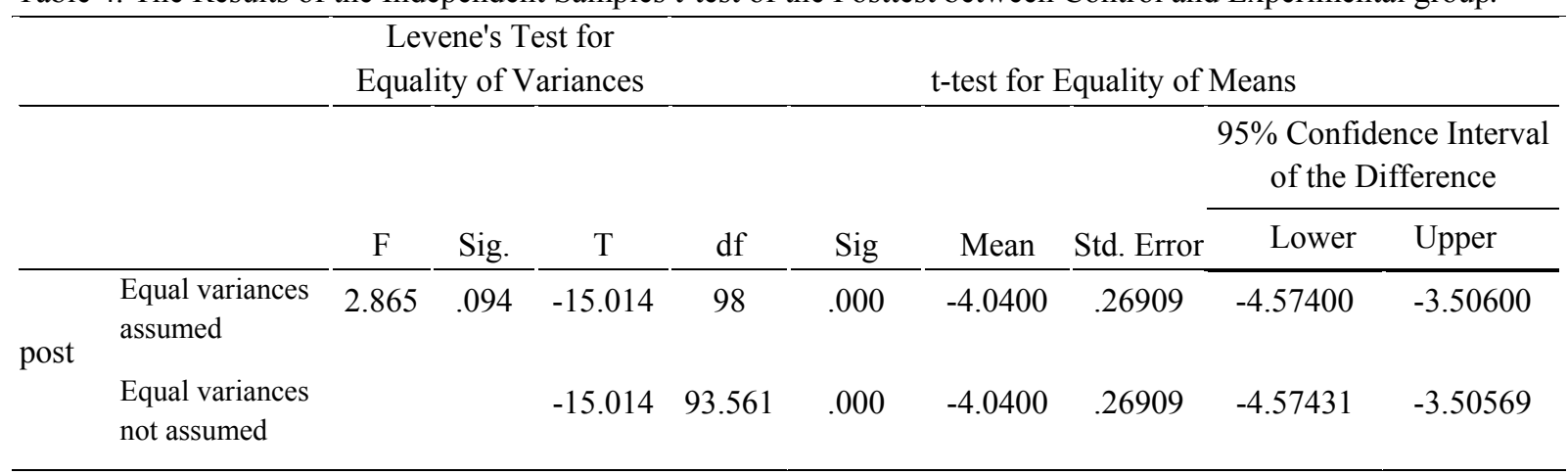

As it is shown, Sig (2-tailed) is .000 , with an alpha $=0.05$; therefore, the difference is statistically significant and that shows that experimental group outperformed control group. As a result, it can be concluded that experimental group did much better than control group on the posttest and that teaching vocabulary via PowerPoint presentation slides turned out to be positive in assisting students with gaining new word families well.

\section{Discussion}

Meaningful differences were observed between the experimental and control groups in vocabulary attainment after implementing the post-test, indicating that achievement in the empirical group improved as a result of Power Point presentation slides instruction. This means that use of power point presentation slides as a supplement of instruction evidenced to be a powerful tool for improving students' achievement in Vocabulary enhancement. This result is congruous with findings of other studies using other forms of technology in language instruction such as the Nagata (1996), Collentine (2000) and Zhuo (1999) studies. Nagata discovered that the progressing intelligent computer feedback is more efficient than simple workbook for developing learners' 
grammatical skill in producing Japanese sentences. Collentine accounted that technologies flourished the abilities of foreign-language learners of Spanish in producing indirect speech. Zhuo came to an end that media centered instruction was very valuable in grammar learning and teaching. Nutta (1998) compared two group of learners based on method of instruction - computerbased instruction versus teacher-guided instruction. She concluded that for all levels of English proficiency, the computer-based students' outperformed teacher guided students.

Differently from Frigaard's study (2002) where the students opted to learn grammar and vocabulary in the classroom environment instead language lab, participants in the study showed interest in learning vocabulary with computer assisted technology. Moreover, the present study unfolded positive effects using Power Point presentation slides on students' vocabulary learning. All in all finding of this endeavor is compatible with findings of other studies. For instance, Lin (2004) found that there is a close and direct relationship between student's attitude toward ESL and computer. If they were competent enough in computer, then it would positively affect their performance in learning. In Chen's study (2004), juniors and seniors students in Taiwan expressed positive attitudes toward pedagogical technology tools in EFL classes. Besides, Felix (2001) reported that on the whole, students were positively inclined to employ technology in their class and reported it incredible, and the majority tried to use the technology as a complement to traditional education.

Additionally, intermediate level college ESL students and teachers showed their positive attitudes toward technologies in the process of learning (Schnackenberg, 1997). The current study paved the way for students to learn vocabulary in non-threatening situation, and the learners enjoyed using the Power point presentation slides and felt it is helpful for them.

The new technology is affecting the language learning partly because it gives rise to better understanding of new vocabularies. In this study technologies were identified not only as a means of instruction but also as a tool of instruction, and students achieved a good repertoire of word family knowledge. Mental tools and environments activate cognitive learning strategies and critical thinking (Jonassen, 1998). Many researches also showed that apart from teaching methodologies, learner's tastes and facilities are other crucial factors that can affect foreign language learning. They encourages learners to become more self-independent and make the learning and acquiring process more practical. There are some researchers who claims that using technologies in every-day teaching and learning contexts is impractical. This is a controversial issue, and we cannot accept because different students at different level of proficiency showed their interests in learning by employing new technologies. As a teacher we should motivate learners to immerse themselves in activities that can be potentially done by technologies, and provide the best situation for constant learning.

Some scientists believe that technology has a charming temptation and they consider some activities rather than examining the pedagogical implications, but here we provided participants with the best uses of technologies. 


\section{Implications and Suggestions for Future Research}

This study provides implications for language teaching pedagogy, curriculum developers, English language teachers, tutors, and definitely learners.

The present study recommends that use of Power Point presentation slides can be expanded to other language levels. Students of different levels (i.e., pre intermediate, intermediate and advanced level) can participate in different courses such as language skills and areas and they can share their Power Point presentation slides in cooperation with their teachers. In order to persuade learners to participate in computer assisted classes, the instructors have to motivate them and the rules of using technologies must be clear. Authorities and families support are also needed for the students to take into account using of technologies seriously. The instruction of the other categories of vocabularies, skills, and areas of language, designing materials and quizzes that are fully delivered by technology are still open for further investigation. Different dimensions of vocabulary such as, oral versus print, receptive versus productive, and breadth versus depth of vocabulary (Kamil \& Hiebert, 2005) are still open for further research.

\section{References}

Aitchison, J. (2003). Words in the Mind. Oxford: Blackwell.

Anderson, R. C., \& Freebody, P. (1981). Vocabulary knowledge. In J. Guthrie (Ed.), Comprehension and teaching: Research reviews (pp. 77-117). Newark, DE: International Reading Association.

Anderson, R., and W. Nagy. 1991. Word meanings. In R. Barr, M. Kamil, P. Mosenthal, and P.D. Pearson, (Eds.), Handbook of Reading Research, Vol. 2, pp. 690-724. New York: Longman.

Baker, S., Simmons, D., \& Kame'enui, E. (1998). Vocabulary acquisition: Synthesis of the research. Washington, DC: U.S. Department of Education, Office of Educational Research and Improvement, Educational Resources Information Center.

Beck, I. L., McKeown, M. G., \& Kucan, L. (2002). Bringing words to life. New York: Guilford.

Biemiller, A. (2001). Teaching vocabulary: Early, direct, and sequential. The American Educator, 25(1), 24-28.

Biemiller, A. (2005). Size and sequence in vocabulary development: Implications for choosing words for primary grade vocabulary instruction. In E. H. Hiebert and M. L. Kamil (Eds.), Teaching and learning vocabulary: Bringing research to practice (pp. 223-242). Mahwah, NJ: Lawrence Erlbaum. Retrieved August 18, 2009, from PsycINFO database.

Chhabra (Eds.), The voice of evidence in reading research. Baltimore, MD: Paul H. Brookes.

Cunningham, A. E. (2005). Vocabulary growth through independent reading and reading aloud to children. In E. H. Hiebert and M. L. Kamil (Eds.), Teaching and learning vocabulary: Bringing research to practice. Mahwah, NJ: Erlbaum.

Cunningham, A.E., \& Stanovich, K.E. (1998). Early reading acquisition and its relation to reading experience and ability 10 years later. Developmental Psychology, 33, 934-945.

Dale, E. (1965). Vocabulary measurement: Techniques and major findings. Elementary English, 42, 895-901. 
Graves, M. F., \& Watts-Taffe, S. M. (2002). The place of word consciousness in a research-based vocabulary program. In S. J. Samuels \& A. E. Farstrup (Eds.), What research has to say about reading instruction (3rd ed., pp. 140165). Newark, DE: International Reading Association.

Kamil, M. L. (2004). Vocabulary and comprehension instruction: Summary and implications of the National Reading Panel findings. In P. McCardle and V.

Kamil, M., \& Hiebert, E. (2005). Teaching and learning vocabulary: Perspectives and persistent issues. In E. H. Hiebert and M. L. Kamil (Eds.), Teaching and learning vocabulary: Bringing research to practice (pp. 1-23). Mahwah, NJ: Lawrence Erlbaum. Retrieved August 18, 2009, from PsycINFO database.

Meara, P. (1987). Vocabulary in a second language, Vol. 2.

Stahl, S. (2005). Four problems with teaching word meanings (and what to do to make vocabulary an integral part of instruction). In E. H. Hiebert and M. L. Kamil (Eds.), Teaching and learning vocabulary: Bringing research to practice (pp. 95-114). Mahwah, NJ: Lawrence Erlbaum. Retrieved August 18, 2016, from PsycINFO database.

Stahl, S. A., \& Kapinus, B. (2001). Word power: What every educator needs to know about teaching vocabulary. Washington, D.C.: National Education Association.

Taylor, Linda (1990) Teaching and Learning Vocabulary. Prentice Hall: New York. 